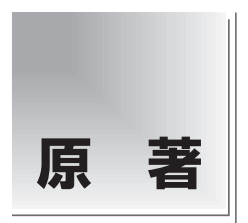

論文受付

2016 年 6 月 2 日

論文受理

2016 年 9 月 29 日

Code No. 500

\section{D-DSA を応用した肝動脈からの \\ 2 相 cone beam computed tomography の検討と臨床応用}

\author{
高尾由範 垣見明彦 片山 豊 佐々木将平 \\ 則政季代 出田真一朗 肥本大輔 市田隆雄
}

大阪市立大学医学部附属病院中央放射線部

\section{緒 言}

血管撮影下 computed tomography $(\mathrm{CT})$ による肝細 胞がんの検出能は極めて高く, 肝動脈化学塞栓術 (transcatheter arterial chemoembolization: TACE)の 術中には血管撮影下 CT を行い結節の局在, 個数およ び性状などを確認することが推奨されている1,2). 特 に腫瘍の動脈血流の変化を鋭敏に反映する肝動脈撮影 下 CT (CT during hepatic arteriography: CTHA)は, 術中情報として有用であり，2 相撮影の後期相で観察
される結節周囲に生じる門脈や静脈への染み出し(コ ロナ様濃染) 像は, 古典的肝細胞がんの鑑別に有用と されている ${ }^{3)}$. CTHAの 2 相撮影は, 造影剂注入後 5 10 秒後から早期相を撮影し, 早期相の終了(造影剤 の注入停止) 後, $20 \sim 40$ 秒程度の時間を拈いて後期相 の撮影が行われることが一般的である ${ }^{4,5)}$. 近年，この ような血管撮影下 CT は, 血管撮影装置を用いて CT 様の画像を得る cone beam computed tomography (CBCT)を用いて行われることが増えており, CBCT

\title{
Clinical Experience of Dual-phase Cone Beam Computed Tomography during Hepatic Arteriography to Apply 3D-DSA
}

Yoshinori Takao, * Akihiko Kakimi, Yutaka Katayama, Shohei Sasaki, Toshiyo Norimasa, Shinichiro Izuta, Daisuke Himoto, and Takao Ichida

Department of Central Radiology, Osaka City University Hospital

Received June 2, 2016; Revision accepted September 29, 2016

Code No. 500

\section{Summary}

We report on the methods and experiences of the dual-phase cone beam computed tomography during hepatic arteriography (CBCTHA) to apply the 3D-DSA. A total of $32 \mathrm{ml}$ contrast medium $(150 \mathrm{mgI} / \mathrm{ml})$ was injected at the rate of $2.0 \mathrm{ml} / \mathrm{s}$ for $16 \mathrm{~s}$. The early phase scan was initiated $10 \mathrm{~s}$ after the start of contrast media injection. The delayed phase scan was started $40 \mathrm{~s}$ after that (24 s after the end of CM injection). When using the dual phase CBCTHA, it was able to obtain the classical hepatocellular carcinoma (HCC) images same as computed tomography during hepatic arteriography (CTHA). In the early phase, the tumor can be highly enhanced against the liver parenchyma. In delayed phase, corona enhancement was clearly appeared at the liver parenchyma. Of 58 cases of acquisitions, we experienced six cases with miss breath holding and 14 cases with over the field of view (FOV) due to hepatomegaly. We evaluated the tumor contrast in 18 cases because the other 40 cases were not applied to our criteria. The pixel values of ROIs on the tumor, coronal enhancement, and liver parenchyma were measured, respectively. Then, we calculated tumor-parenchyma contrast ( $\mathrm{T}-\mathrm{P}$ contrast), corona-tumor contrast (C-T contrast), and corona-parenchyma contrast (C-P contrast). The T-P contrast was $358 \pm 112$, the C-T contrast was $132 \pm 51$, and the C-P contrast was $168 \pm 66$. The contrast was clearly visualized among them. The dual-phase CBCTHA that applies the 3D-DSA is a simple and useful technique for hepatocellular carcinoma treatment.

Key words: cone beam computed tomography during hepatic arteriography (CBCTHA), cone beam computed tomography $(\mathrm{CBCT})$, hepatocellular carcinoma $(\mathrm{HCC})$, coronal enhancement, contrast enhancement

\footnotetext{
*Proceeding author
} 
Table 1 Patients background

\begin{tabular}{lc}
\hline \hline Examinations & 64 \\
Patients & 58 \\
Male/Female & $33 / 25$ \\
Height $(\mathrm{cm})^{*}$ & $159.8 \pm 9.1$ \\
Weight $(\mathrm{kg})^{*}$ & $62.0 \pm 15.1$ \\
Age* $^{*}$ & $70.2 \pm 12.3$ \\
\hline
\end{tabular}

*Mean \pm standard deviation (SD)

を用いた CTHA (CBCTHA) に関する報告も散見され

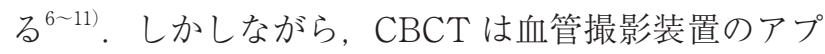
リケーションの一つであるため, CT と比較して性能 や汎用性に劣る，特に field of view (FOV)が狭い，低 コントラスト検出能や時間分解能に劣る, 複数時相の 撮影が難しい，プロトコルの汎用性がそしいなどの点 は使用に扔ける問題とされる に関する報告は単相の撮影が中心であり ${ }^{6,7.9)}$, 複数時 相の撮影に関する報告は複数時相の撮影が容易な一部

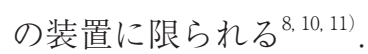

本稿では，血管撮影装置に掞ける一般的な撮影技術 である 3D-DSA の撮影手法を応用した CBCTHA の 2 相撮影 (2 相 CBCTHA)の手法と経験について報告 する。

\section{1. 方 法}

\section{1-1 倫理的配慮および対象}

本研究は, 本学の倫理委員会で承認された計画書に 基づき実施し, 臨床画像の使用に関しては, すべて匿 名化している(承認番号 2615)。

対象は, 2013 年 5 月 1 日から 11 月 30 日の期間に肝 がんを対象として実施した interventional radiology (IVR)の術中に 2 相 CBCTHA を施行した 64 撮影 (58 症例)である(Table 1)。対象者は男性 33 例，女性 25 例，年齢 $70.2 \pm 12.3$ 歳，身長 $159.8 \pm 9.1 \mathrm{~cm}$, 体重 $62.0 \pm$
$15.1 \mathrm{~kg}$ であった.

\section{1-2 使用機器}

血管撮影装置はArtis Zee BA Twin(シーメンスヘ ルスケア・ジャパン株式会社)を使用した。本装置は, $154 \mu \mathrm{m}$ のピクセルサイズを有する CsI の flat panel detector (FPD)を備えた床置き式の正面アームと天井 懸垂式の側面アームを有する血管撮影装置である。

CBCT 撮影は, 頭方向からCアームを挿入し, プロペ ラ回転で実施する。自動注入器は, Press Duo(株式会 社根本杏林堂)を使用した。本装置は 2 筒式であるた め, それぞれの注入条件を独立，あるいは連動して制 御できる.

\section{1-3 CBCTHA の撮影}

\section{1-3-1 撮影パラメータの選択}

今回使用した撮影および再構成条件の概要を示す (Table 2). 本撮影条件は, 装置にプリセットされた 撮影条件の中で最も低コントラスト検出能のよい画像 を高速に取得できる条件である。元画像は $29.6 \times 38.2$ $\mathrm{cm}$ の FPD で, 480×616 マトリクスで取得され， 6 秒 の撮影時間において $200^{\circ}$ 回転し, 368 枚の画像を取得 する。管電圧は $90 \mathrm{kV}$ ，パルス幅は $5 \mathrm{ms，1} \mathrm{フレーム}$ あたりの検出器入射線量は $0.36 \mu \mathrm{Gy}$ である。撮影条 件は，入射線量のモニタリングにより1フレームごと に変化し, 管電流, パルス幅, 管電圧の順に変化し, 必要な検出器入射線量を保つ. 回転デー夕は付属の ワークステーション (syngo X-Workplace VB21C) に転 送され再構成される。

\section{1-3-2 2 相撮影の手法}

本装置で行うことができる 2 相撮影の手法には, 単 独の CBCT 撮影を 2 回実施する手法と 3D-DSA で使 用される 2 相撮影プログラムを応用する手法がある. 血管撮影装置のCアームを回転させて投影デー夕を

Table 2 Imaging and reconstruction conditions

\begin{tabular}{lclcc}
\hline \multicolumn{1}{c}{ Scan } & & \multicolumn{2}{c}{ Reconstruction } \\
\hline Voltage $(\mathrm{kV})$ & 90 & Matrix & $512 \times 512$ \\
Pulse width $(\mathrm{ms})$ & 5 & Kernel & HU \\
Detector dose $(\mu \mathrm{Gy} /$ frame) & 0.360 & Image characteristics & Normal \\
Rotation angle $\left({ }^{\circ}\right)$ & 200 & Reconstruction & Nat Fill \\
Projections (views) & 368 & WC & 250 \\
Scan time (s) & 6 & WW & 650 \\
Image matrix (pixels) & $480 \times 616$ & & \\
Processing mode & DSA Sub & & \\
3D type & DSA & & \\
3D control & Manual & & \\
\hline
\end{tabular}


収集する CBCTでは, 被験者の安全確認を目的とし た test run を撮影前に実施しなくてはならない. CT 装置のような多時相撮影が行える仕様を有していない 装置も多いため, 撮影プログラムの選択ごとに test run を行う必要がある。この操作には 20 秒程度を要 するため, 単独の撮影を 2 回行う場合には, プログラ ム選択やCアームの操作に並行して被験者に対する 呼吸停止の指示を行う必要がある。一方, 3D-DSA で 使用している 2 相撮影プログラムを応用する場合に は, これらの操作は一連のプロトコルに含まれ，撮影 前のプログラムの選択と test run は不要となる。更 に, C アームは自動的かつ速やかに撮影開始位置にス タンバイされるため, 操作者は十分な時間的余裕のも と被験者に呼吸停止の指示を行うことができる.今回 使用した装置における 1 相目の撮影終了から 2 相目の 撮影開始までの最短時間は 7 秒程度である。本稿では 3D-DSA を応用した 2 相 CBCTHA を検討し臨床に応 用した。

\section{1-3-3 3D-DSA の応用}

3D-DSA では, 造影剤を注入しない単純撮影相 (mask phase)の撮影を行った後, 血管内に造影剤が充 満した造影相 (contrast phase)の撮影を行う。撮影後, contrast phase から mask phase をサブトラクション

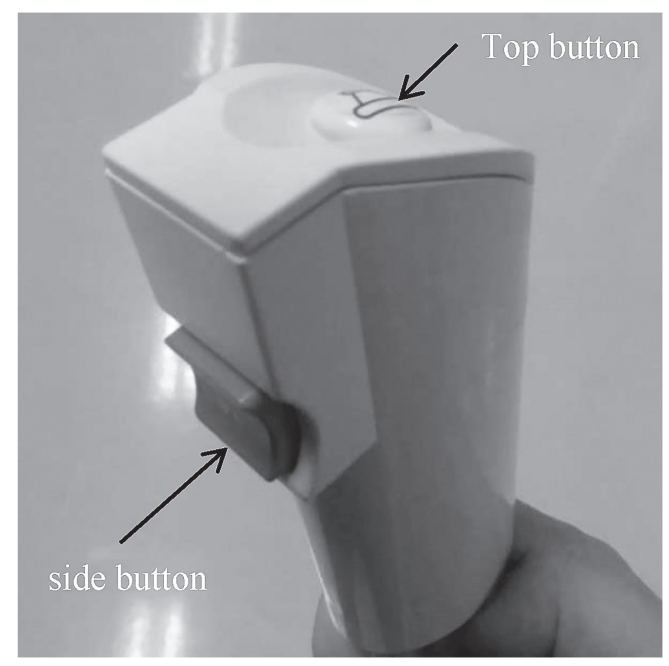

Fig. 1 Hand switch for use in the examinations.
することで，造影剤が満たされた血管造影像を容易に 取得できる。今回, mask phase と contrast phase を それぞれ，早期相および後期相画像として再構成する ことで，CBCTを用いた 2 相撮影を実現した。また， 任意の撮影夕イミングでの 2 相撮影を実施するために マニュアル DSA モードを使用した.

本撮影モードは, 手動操作ではあるが任意の撮影夕 イミングで 2 相の撮影を行うことができる撮影モード である。ハンドスイッチ上部に設けられたボタン (トップボタン)に加えて側面に備えられたボタン(サ イドボタン)も使用する(Fig. 1)。撮影時は, トップボ タンを押した状態を保ちながら，サイドボタンを押す ことにより任意のタイミングで撮影を開始できる。 トップボタンは，Cアームの動き(回転)にも連動する ため，撮影のすべてが終了するまでその状態を保つ.

\section{1-3-4 インジェクタの設定}

インジェクタと連動させて 3D-DSA を行う場合, 造 影剂の注入は mask phase ではなく, contrast phase に対して連動する. CTHA では，1相目の撮影に先行 して造影剂を注入する必要があるため, 血管撮影装置 とインジェクタが連動しないIVR-CT モードを使用した。

2 筒式のインジェクタの一方に造影剤(オムニパー ク $300 \mathrm{mgI} / \mathrm{ml}$ : イオヘキソール, 第一三共株式会 社), もう一方に生理食塩水 (大塚製薬株式会社)を充 填し, 同時注入によりスパイラルチューブ(株式会社 根本杏林堂) 内で両者を 1 対 1 で混合し希釈 (150 $\mathrm{mgI} / \mathrm{ml}$ ) した後, カテーテルを介して血管内に注入す るように設定した。

\section{1-3-5 CBCTHA の撮影}

CBCTHA の目的は CTHA と同様に肝細胞がんの 血行動態を画像として描出することであり，早期相で は腫瘍や栄養血管, 後期相ではコロナ様濃染像の描出 などを目的に施行される。CTHAにおける肝細胞が んの至適撮影タイミングは血行動態の解析などから明 らかとなっており ${ }^{3,4)}$. CBCTHA の撮影時間 6 秒は CTHA の撮影時間とほぼ同等である。そのため, 早 期相ならびに後期相の撮影開始時間や造影剤注入条件 はCTHA に準じた(Fig. 2)，造影は，総肝動脈あるい

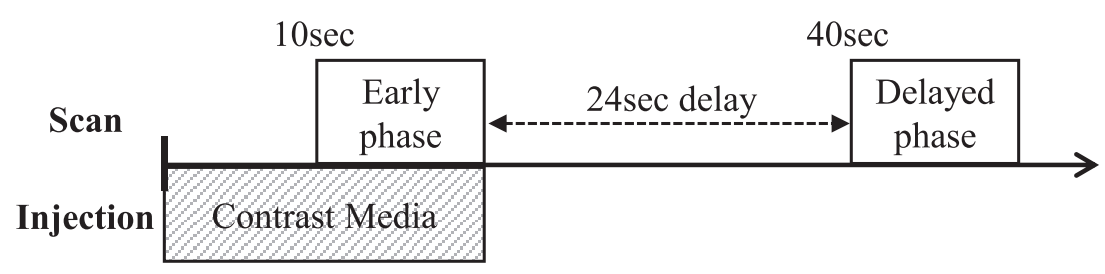

Fig. 2 Examination of the Dual-phase CBCTHA. 
は固有肝動脈に留置したカテーテルから行った。造影 剤 $32 \mathrm{ml}(150 \mathrm{mgI} / \mathrm{ml})$ を $2.0 \mathrm{ml} / \mathrm{s}, 16$ 秒注入するプロ トコルを基本とし，右肝動脈-上腸間膜動脈起始など 血管床の減少を伴う破格を有する症例では，注入レー トのみを減じた。早期相は，肝細胞がんが十分に造影 される造影剂注入開始から 10 秒に手動で撮影を開始 した。後期相は, コロナ様濃染像が明瞭に描出される 造影剂注入停止から 24 秒 (造影剤注入開始から 40 秒) に手動で撮影を開始した。造影剤の注入停止は，早期 相の撮影終了時間と一致させた。

撮影は, 血管撮影に準じて呼気呼吸停止下で行っ た。室時および CBCTHA 施行直前に十分な呼吸停 止練習を行い, 撮影直前には, 造影剂注入時に生じる 腹部の熱感についても十分に説明を行った.

\section{1-4 造影効果の検証}

造影効果の検証の対象は, 治療の 1 カ月以内に実施 したダイナミック CT あるい dynamic magnetic resonance image(ダイナミック MRI)の早期相で濃染 する結節を有する症例で， かつ除外項目 (体重 $40 \mathrm{~kg}$ 未満, 体重 $80 \mathrm{~kg}$ 以上, 内部に壊死を伴う結節, 混合 型肝細胞がんの症例)に該当しない 18 症例 (19 撮影) とした，対象とする結節は，早期相で濃染され後期相 でコロナ様濃染を認める 10 30 mm $\phi(\mathrm{CBCTHA}$ の 早期相で計測)の 31 結節とした。破格を有さない 15 症例 (15 撮影)の造影剤注入レートは, $2.0 \mathrm{ml} / \mathrm{s}$ であ り, 右肝動脈-上腸間膜動脈起始の 3 例のうち, 左葉の 治療が不要であった 2 症例 ( 2 撮影) は, 右肝動脈より 1.5 および $1.7 \mathrm{ml} / \mathrm{s}$ で造影剤を注入し, 左葉の治療を 要した 1 症例 ( 2 撮影) は右肝動脈より $1.5 \mathrm{ml} / \mathrm{s}$, 左肝 動脈より $1.2 \mathrm{ml} / \mathrm{s}$ で造影剤を注入し撮影を行った。

計測は血管撮影装置に備えられたワークステーショ ンで実施した。横断像にて早期相ならびに後期相の各 部に region of interest(ROI)を設定し，ピクセル值を 計測した，本装置で計測されるピクセル值は CT 值に 近似した装置固有の值である。早期相では肝動脈近位 部 (肝動脈), 腫瘍, 腫瘍近傍の肝実質 (肝実質)に約 2 $\mathrm{mm} \phi$, 約 $10 \mathrm{~mm} \phi$, 約 $15 \mathrm{~mm} \phi$ の ROI を設定した. また，計測した值を用いて腫瘍と肝実質のピクセル值 差(tumor-parenchyma contrast: T-P コントラスト)を 算出した(式 1 )。後期相では, 腫瘍, コロナ様濃染部, 腫瘍近傍の肝実質に約 $10 \mathrm{~mm} \phi$, 約 $1.5 \mathrm{~mm} \phi$, 約 15 $\mathrm{mm} \phi$ の ROI を設定した。また，計測した值を用いて コロナ様濃染部と腫瘍のピクセル值差 (corona-tumor contrast: C-T コントラスト) 拈よびコロナ様濃染部と 腫瘍近傍の肝実質のピクセル值差 (corona-
Table 3 Result of the Dual-phase CBCTHA

\begin{tabular}{lcc}
\hline \hline Cather position & CHA & 49 \\
& LHA & 5 \\
& RHA (Replaced RHA) & $8(7)$ \\
& MHA & 1 \\
\hline Over the FOV & X-Y-Z & $4^{*}$ \\
& X-Y & 7 \\
Z & $3^{*}$ \\
\hline Breath hold miss & Early phase & 6 \\
& Delayed phase & 1 \\
\hline
\end{tabular}

* Include a case of huge HCC (over $100 \mathrm{~mm} \varphi$ )

parenchyma contrast: C-P コントラスト)を算出した （式 2,3）.

$T-P$ contrast $=R O I_{t}-R O I_{p}$

$C-T$ contrast $=R O I_{c}-R O I_{t}$

$C-P$ contrast $=R O I_{c}-R O I_{p}$

$R O I_{t}$ : Pixel value of the tumor area

$R O I_{p}$ : Pixel value of the parenchyma area

$R O I_{c}$ : Pixel value of the corona enhancement area

各 ROI の計測は同一断面で 2 回実施し, 2 回の平均 值を結節のピクセル值として評価した。 また 1 症例で 複数の結節を有する症例については, すべての結節の 平均値を症例の代表值として取り扱った。

\section{2. 結 果}

\section{2-1 撮影の結果}

64 撮影 (58 症例) の 2 相 CBCTHA の結果を示す (Table 3). 総肝動脈造影が 49 撮影, 左肝動脈造影が 5 撮影, 右肝動脈造影が 8 撮影 (右肝動脈-上腸間膜動 脈起始 7 例を含む), 中肝動脈造影が 1 撮影であった. FOV に全肝を含めて撮影できなかった症例は 14 症例 あった，X-Y 平面および Z 軸方向 $(X-Y-Z)$ で全肝を含 めて撮影できなかった症例は 4 症例 (100 $\mathrm{mm} \phi$ 超える 巨大肝腫瘍 1 症例を含む), $\mathrm{X}-\mathrm{Y}$ 平面のみ $(\mathrm{X}-\mathrm{Y})$ は 7 症例， $Z$ 軸方向のみ $(Z)$ は 3 症例 $(100 \mathrm{~mm} \phi$ を超える 巨大肝腫瘍症例 1 症例を含む)であった。呼吸停止不 良は早期相 6 撮影, 後期相 1 撮影で認めた。後期相で 呼吸停止不良であった症例は, 早期相でも呼吸停止不 良であった。 


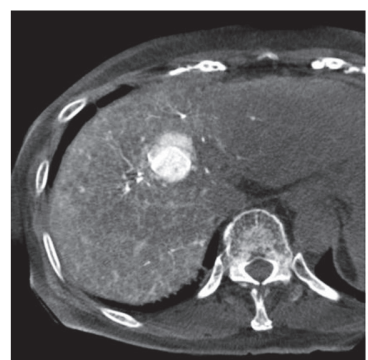

Fig. 3 Dual-phase CBCTHA images.

(a) Early phase image

(b) Delayed phase image

(c) MIP image (Early phase)
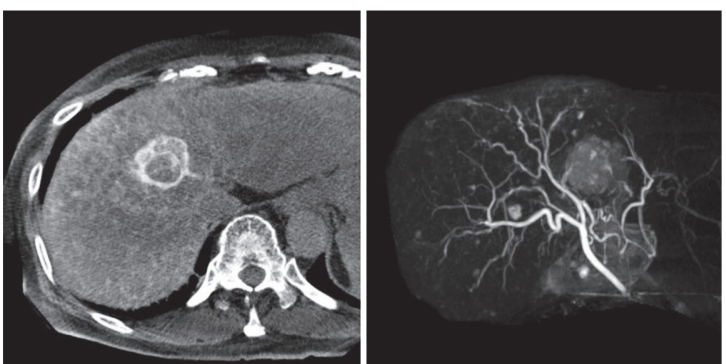

$\mathrm{a}|\mathrm{b}| \mathrm{c}$
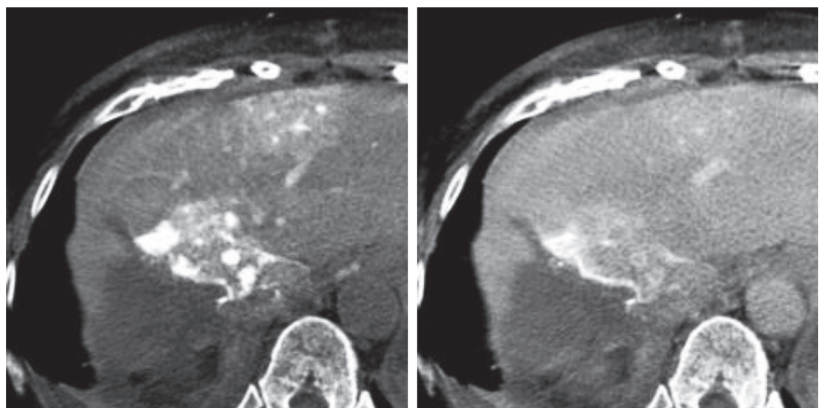

Fig. 4 Dual-phase CBCTHA images (small HCCs).

(a) Early phase image

(b) Delayed phase image
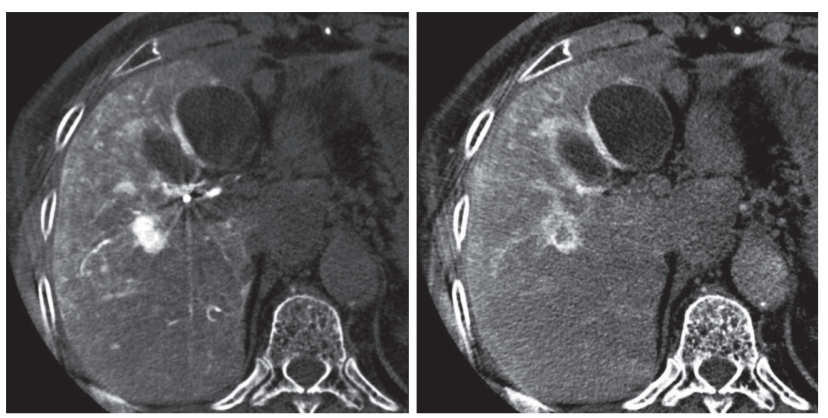

Fig. 5 Artifacts on the Dual-phase CBCTHA images. a b

(a) Early phase: Show the streak artifacts due to the hepatic artery motion and under sampling

(b) Delayed phase: The streak artifacts are not shown, however artifact at the surrounding ribs are remained.

\section{2-2 画像の例示}

古典的肝細胞がんの結節は, 早期相で濃染され, 後 期相でコロナ様濃染を示した。早期相から作成した minimum intensity projection(MIP)では細かな血管も 描出することができた (Fig. 3). 小肝腫瘍においても 同様に結節の血行動態を反映した造影効果を認めた (Fig. 4). また, 早期相では, 造影血管の拍動に起因 するストリークアーチファクトを血管の周囲に生じた
Table 4 Contrast enhancement effect in Dual-phase CBCTHA images

\begin{tabular}{lcc}
\hline \hline & Measured points & $\begin{array}{c}\text { Pixel value } \\
\text { mean } \pm \text { SD }\end{array}$ \\
\hline Early phase & Hepatic artery & $1222 \pm 320$ \\
& Tumor & $524 \pm 139$ \\
& Parenchyma & $166 \pm 41$ \\
\cline { 2 - 3 } & T-P contrast & $358 \pm 112$ \\
\hline Delayed phase & Tumor & $165 \pm 59$ \\
& Corona & $297 \pm 95$ \\
& Parenchyma & $135 \pm 35$ \\
\cline { 2 - 3 } & C-T contrast & $132 \pm 51$ \\
& C-P contrast & $168 \pm 66$ \\
\hline
\end{tabular}

$\mathrm{n}=18,31$ lesions, Tumor diameter: $16.6 \pm 7.1 \mathrm{~mm}$

が，後期相では消失した (Fig. 5). ビームハードニン グやトランケーションアーチファクトに起因する胁骨 の周囲の線状陰影は多くの画像で観察された .

\section{2-3 各部の造影効果}

各部の造影効果を示す (Table 4)。早期相の画像に 設定した ROI における平均ピクセル值と標準偏差は, 肝動脈 $1222 \pm 320$, 腫痬 $524 \pm 139$, 肝実質 $166 \pm 41$ で あった。また，T-P コントラストは $358 \pm 112$ であっ た。後期相の画像に設定した ROI の平均ピクセル值 と標準偏差は, 腫瘍 $165 \pm 59$, コロナ様濃染部 $297 \pm 95$, 肝実質 $135 \pm 35$ であった。また，C-T コントラストは

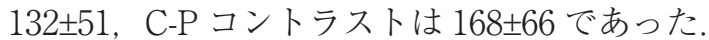

\section{3. 考 察}

\section{3-1 造影効果の妥当性}

本法を用いた場合の結節のピクセル值差は T-P コ ントラスト $358 \pm 112$, C-T コントラスト $132 \pm 51$ ， C-P コントラスト $168 \pm 66$ であった。これはダイナミック CT おける結節と肝実質の CT 值差 (35 HU 程度) と比 
較しても十分なピクセル值の差を有している ${ }^{12}$. その ため, ダイナミック CT やダイナミック MRI を用い て検出される結節は確実に描出できると考える.

\section{3-2 空間分解能が高いことによる有意}

詳細な検討は行えていないが今回経験した 58 症例 では, $5 \mathrm{~mm}$ 程度の結節に扔けるコロナ様濃染や栄養 動脈などの細血管も描出されていた。これは, CBCT が有する高い空間分解能が微細な構造の描出に寄与し たものと考える ${ }^{13)}$. 近年の TACEの主流はマイクロ カテーテルを用いて区域あるいは，亜区域枝レベルの 血管を選択して行う選択的 TACE である。しかし一 方で，更に末梢の血管を選択して結節のみを選択的に 治療する超選択的 TACEも積極的に行われるように なっている ${ }^{6,14,15)}$. 末梢血管の描出能に優れる $\mathrm{CBCT}$ を使用することで, 超選択的 TACE で求められる栄 養血管の描出や小肝腫瘍の描出も容易と考元る.

\section{3-3 プロトコルの汎用性と CBCT の使用で生じる問} 題点の解決

本法で使用した撮影タイミングや造影法は, 異なる 装置や 3D-DSA を応用しない撮影手法においても応 用することができる。

結節のコントラストは, 低コントラスト検出能に優 れる装置では造影剤濃度を低く設定し, 劣る装置では 造影剤濃度を高く設定することで調整できる，撮影を 開始する時間は，肝細胞がんの血行動態に依存するた め撮影装置で変化しない。早期相は, 結節が濃染する 5〜10 秒程度の時間を設けた後に撮影を開始し，早期 相の終了時まで造影剤の注入を持続し，後期相は, コ ロナ様濃染が出現する造影剤の注入停止後 20 40 秒 後に撮影することで CBCT を用いても CTHA に類似 した画像を取得できる。後期相の撮影を一連のプロト コルとして実施できない場合には，撮影開始時間の 20〜40 秒前に造影剤の注入を停止することでコロナ 様濃染像の描出が可能である ${ }^{16)}$.

CBCT を使用することでさまざまな問題が生じる が，その多くは撮影時の工夫で解決できる, ${ }^{513)}$. FOV が狭い (X-Y 平面で $270 \mathrm{~mm}, Z$ 軸方向で $150 \mathrm{~mm}$ 程 度)ため, 肝腫大を呈することが多い肝がん症例のす ベてで全肝を FOV に含めて撮影することは難しく， 今回の検討でも 14 症例で撮影できていない，この問 題は撮影の目的あるいは撮影部位を明確にして撮影を 行うことで解決できると考える。
CBCTHA の撮影は十分な呼吸停止練習の後に実施 したが，数例で呼吸停止不良に起因するアーチファク トを生じた。また，呼吸停止不良は早期相に集中して 発生しており, 造影剂注入時の熱感に起因する呼吸停 止不良と考えられた，CBCT は CT と比較してわず かな動きや呼吸の乱れがアーチファクトとして検出さ れる可能性が高い. 呼吸停止不良の多くは, 被験者に 対するインフォームド・コンセントの充足により解決 できると考える。

早期相で生じる血管の拍動に起因するストリーク アーチファクトの抜本的な改善は, 現段階においては 難しいと考える。しかし, 金属アーチファクト低減処 理をはじめとする種々の補正処理により改善できる可 能性は高いと考える ${ }^{17)}$.

本稿は, 2 相 CBTCTHA の撮影手法に関する報告 であり, CBCTHA の検出能を評価した報告ではない. 今後, CBCTHA を使用した結節の検出能についても 検証が必要と考える。最新の血管撮影装置は $\mathrm{CBCT}$ 機能を備えることが一般的となっているが, 複数時相 の撮影を一連のプロトコルとして行える装置は限られ ている. CBCT の活用を進めるためには, 装置の自由 度の向上が不可欠と考える.

\section{4. 結 語}

本稿では, 3D-DSA の撮影手法を応用した 2 相 CBCTHA の手法と経験について報告した。簡便に施 行できる本法は, 肝細胞がんの IVR に有用な撮影技 術である。

\section{謝 辞}

2 相 CBCTHA の導入にあたりご指導，ご協力を賜 りした元大阪市立大学大学院医学研究科放射線診断 学・IVR 学の西田典史様, 堺 幸正様, 大阪市立大学 大学院医学研究科放射線診断学. IVR 学の羽室雅夫 様, 濱本晋一様ならびに医師の皆様, シーメンスヘル スケア株式会社の新井田紀光様, 福田 毅様, 大里 肇様, 小嶋 嚴様, シヘブ・ダマニ様, 大阪市立大学 医学部附属病院中央放射線部の皆様に深く感謝申し上 げます。

なお, 本報告の要旨は, 第 41 回日本放射線技術学会 秋季学術大会 (2013 年, 福岡)ならびに第 70 回日本放 射線技術学会 総会学術大会 (2014 年, 横浜)にて報告 した。 


\section{参考文献}

1）日本肝臓学会編．科学的根拠に基づく肝癌診療ガイドラ イン 2013 年版. 東京 : 金原出版. 2013.

2) 日本肝臓学会編. 肝癌診療マニュアル第 3 版. 東京：医 学書院. 2015.

3) Ueda K, Matsui O, Kawamori $Y$, et al. Hypervascular hepatocellular carcinoma: evaluation of hemodynamics with dynamic CT during hepatic arteriography. Radiology 1998; 206 (1): 161-166.

4）南 哲弥, 小林 聡, 香田 涉, 他. 早期肝癌の診断にお ける CTHA/CTAPの意義一肝癌診療ガイドラインにおけ る位置づけ一。肝胆膵画像 2009; 11(1): 17-23.

5) 日本放射線技術学会. 放射線医療技術学叢書 (34) Interventional Radiologic Technology. 日本放射線技術学 会, 京都, 2015: 93-109.

6) Miyayama S, Yamashiro M, Okuda M, et al. Usefulness of cone-beam computed tomography during ultraselective transcatheter arterial chemoembolization for small hepatocellular carcinomas that cannot be demonstrated on angiography. Cardiovasc Intervent Radiol 2009; 32(2): 255-264.

7) Syha R, Grözinger G, Grosse U, et al. C-arm computed tomography parenchymal blood volume measurement in evaluation of hepatocellular carcinoma before transarterial chemoembolization with drug eluting beads. Cancer Imaging 2015; 15: 22.

8) Miyayama S, Yamashiro M, Okuda M, et al. Detection of corona enhancement of hypervascular hepatocellular carcinoma by $\mathrm{C}$-arm dual-phase cone-beam CT during hepatic arteriography. Cardiovasc Intervent Radiol 2011; 34(1): 81-86.

9) Miyayama S, Yamashiro M, Hashimoto M, et al. Comparison of local control in transcatheter arterial chemoembolization of hepatocellular carcinoma $\leq 6 \mathrm{~cm}$ with or without intraprocedural monitoring of the embolized area using cone-beam computed tomography. Cardiovase Intervent Radiol 2014; 37(2): 388-395.

10) Pellerin $\mathrm{O}$, Lin $\mathrm{M}$, Bhagat $\mathrm{N}$, et al. Can $\mathrm{C}$-arm cone-beam $\mathrm{CT}$ detect a micro-embolic effect after TheraSphere radioembolization of neuroendocrine and carcinoid liver metastasis? Cancer Biother Radiopharm 2013; 28(6): 459-465.

11) Schernthaner RE, Lin M, Duran R, et al. Delayed-Phase ConeBeam CT Improves Detectability of Intrahepatic Cholangiocarcinoma During Conventional Transarterial Chemoembolization. Cardiovasc Intervent Radiol 2015; 38(4): 929-936.

12）吉川秀司, 岡田真広, 近藤浩史, 他. 多施設共同研究によ る肝細胞癌診断のための Bolus Tracking を使用した CT 検 查における動脈優位相撮影の造影方法および設定值の検 討. 日放技学誌 2014: 70(8): 805-813.

13）日本放射線技術学会. 放射線医療技術学叢書 (34) Interventional Radiologic Technology. 日本放射線技術学 会, 京都, 2015: 120-131.

14) Shimohira $M$, Ogino $H$, Kawai $T$, et al. Use of the triaxial microcatheter method in super-selective transcatheter arterial chemoembolisation for hepatocellular carcinoma. Br J Radiol 2011; 84(998): 184-187.

15) Imai $N$, Ishigami $M$, Ishizu $Y$, et al. Transarterial chemoembolization for hepatocellular carcinoma: A review of techniques. World J Hepatol 2014; 6(12): 844-850.

16）芦田信示, 岡田光正. 肝細胞がんの血管造影診断におけ る先進的取り組み一肝細胞がん IVR 治療の現状と展 望一. Innervision 2008; 23: 25-29.

17) Boas FE, Fleischmann D. CT artifacts: causes and reduction techniques. Imaging Med 2012; 4(2): 229-240. 